\title{
APLIKASI LAYANAN ANGKUTAN KAPAL DI PT. PELAYARAN TEMPURAN EMAS, TBK BANJARMASIN BERBASIS WEB
}

\author{
Indu Indah Purnomo $\left.{ }^{1}\right)$ \\ ${ }^{1,}$ Fakultas Teknologi Informasi, Universitas Islam Kalimantan Muhammmad Arsyad Al Banjari Banjarmasin Jalan \\ Adhyaksa No.2 Kayu Tangi Banjarmasin 70123 \\ e-mail: indumbc@gmail.com
}

\begin{abstract}
ABSTRAK
Dermaga merupakan sebuah fasilitas di sungai, atau danau untuk menerima kapal dan memindahkan barang. Perkembangan dermaga sangat ditentukan aktivitas perdagangannya, semakin ramai aktivitas perdagangan didermaga tersebut maka akan semakin besar dermaga tersebut. Perkembangan perdagangan juga mempengaruhi jenis kapal dan lalu lintas kapal yang melewati dermaga tersebut, dengan demikian perkembangannya lalu lintas angkutan laut, teknologi bongkar muat, hal ini menuntut dermaga dalam meningkatkan kualitas peran dan fungsinya sebagai terminal point bagi barang dan kapal. Oleh karena itu, setiap daerah berusaha membangun dan mengembangkan dermaganya sesuai dengan tingkat keramaian dan jenis perdagangan yang ditampung oleh dermaga tersebut. Dinas perhubungan komunikasi dan informatika merupakan salah satu organisasi yang ada dalam kegiatan dermaga yang menangani kegiatan membongkar muatan kapal, penanganan bongkar muat kapal meliputi membongkar dan memuat isi muatan kapal yang mana setiap kapal memiliki jenis muatan tersendiri. Dari hasil penelitian yang telah dilakukan diperoleh dari kesimpulan Aplikasi dapat dijadikan sebagai pelengkap dari kegiatan Bongkar Muat barang, dimana aplikasi ini menawarkan sesuatu yang daoat mempermudah dalam pendataan serta memberikan laporan yang akurat.
\end{abstract}

Kata Kunci : Aplikasi, Bongkar Muat Barang, Kapal

\section{PENDAHULUAN}

Pencatatan jadwal bongkar muat kapal merupakan suatu kegiatan khusus untuk menyediakan informasi data bongkar muat kapal ke pelabuhan. Untuk mengefektifkan dan mengefisiensikan fungsi penyediaan informasi tersebut, diperlukan suatu sistem informasi yang khusus untuk mencatat dan menyediakan data serta menghasilkan informasi yang akurat kepada pihak yang berwenang dalam penyelenggaraan dasar pengambilan keputusan pimpinan.
Pencatatan yang dimaksud yakni apabila kapal tersebut masuk ke pelabuhan maka bagian administrasi

langsung memberikan formulir bongkar muat barang kepada pihak pemilik kapal. Setelah pihak pemilik kapal tersebut menyerahkan ke bagian administrasi dan pada akhir bulan (setelah 30 hari kerja) Bagian administrasi akan merekapitulasi seluruh formulir yang ada dengan menggunakan excel, adapun yang menjadi beberapa kekurangan sistem saat ini misalnya pencatatan transaksi berdasarkan formulir yang diberikan memerlukan waktu yang lama 
\pm 10 menit untuk setiap transaksi, penyajian informasi kurang akurat serta terdapat redudancy (tumpang tindih) dokumen. Berdasarkan dengan hasil yang diperoleh di atas, maka yang menjadi masalah dalam penelitian ini yakni kurangnya efektivitas dan efisiensi dalam hal kinerja bagian administrasi dalam mencatat data bongkar muat kapal sehingga menghasilkan produktivitas kinerja yang rendah. Hal ini disebabkan karena pencatatan atau proses rekapitulasi membutuhkan waktu yang relatif lama Adapun yang menjadi kelebihan pencatatan system informasi perkapalan dengan menggunakan PHP yakni dapat membantu meningkatkan kinerja, produktivitas serta efisiensi pegawai bagian administrasi yang ada pada PT. Pelayaran Tempuran Emas, Tbk Banjarmasin. Oleh karena itu, diharapkan dengan adanya penelitian ini dapat membantu pihak bersangkutan dari segi proses pencatatan data bongkar muat kapal sampai menyajikan informasi yang akurat, tepat dan cepat bagi pihak-pihak yang membutuhkan.

\section{METODE PENELITIAN}

\section{A. Kepustakaan}

Merupakan pengumpulan data dengan cara pengambilan data - data dari catatan kuliah serta buku - buku dan juga melakukan pencarian media internet untuk mendapatkan hal yang ada kaitanya dengan dengan desain dan perancangan sistem informasi.

B. Metode Observasi

Metode Observasi adalah sistem pengumpulan data dengan cara melakukan pengamatan secara langsung pada objek yang diteliti, sehingga didapatkan data yang akurat.

C. Wawancara
Melakukan Tanya jawab dengan pihak tempat penulisan melakukan penelitian

D. Perancangan

Metode perancangan adalah metode dengan cara merancang dan membuat profil untuk kepentingan informasi dengan sistem informasi.

E. Metode Uji Coba

Penulis melakukan uji coba dari sistem informasi administrasi yang telah dibuat secara keseluruhan sebelum di implementasikan di kantor.

F. Metode Implementasi

Pada tahapan ini sistem di implementasikan secara keseluruhan sebagai akhir pembangunan perangkat.

\section{Rancangan Model Sistem}

Pada rancangan model sistem ini akan membahas gambaran kebutuhan sistem yang akan dibangun. DFD ( Data Flow Diagram) yang memiliki 3 tahapan yaitu: diagram kontek, diagram Kontek level 0, Class Diagram.

\section{A. Data Flow Diagram (DFD)}

Pada diagram DFD akan membahas alur sistem hubungan antara user dan sistem, pada DFD diagram ini membahas kebutuhan sistem dari sudut pandang user/pengguna.

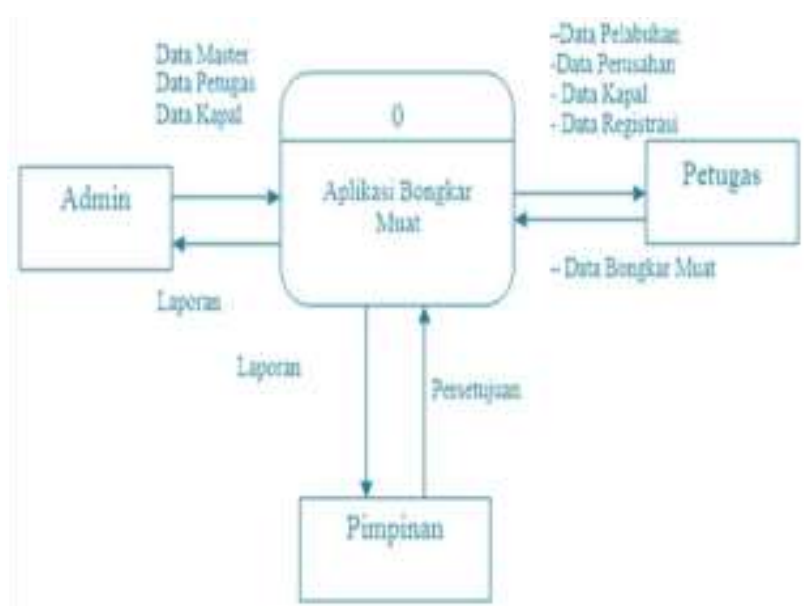

\section{B. Data Flow Diagram (DFD) Level 0}

Pada diagram ini membahas alur sistem dari yang diagram kontek ke diagram kontek level 0 dari hasil validasi di diagram kontek 


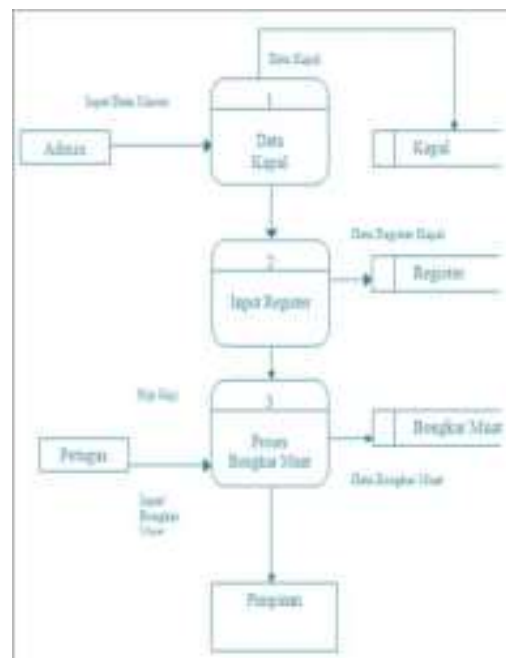

\section{Class Diagram}

Class diagram mendeskripsikan jenis-jenis objek dalam sistem dan berbagai macam hubungan statis yang terdapat diantara mereka. Class diagram Penerapan Aplikasi Layanan angkutan Kapal di PT. Pelayaran Tempuran Emas, TBK Banjarmasin Berbasis Web dapat dilihat pada gambar dibawah ini :

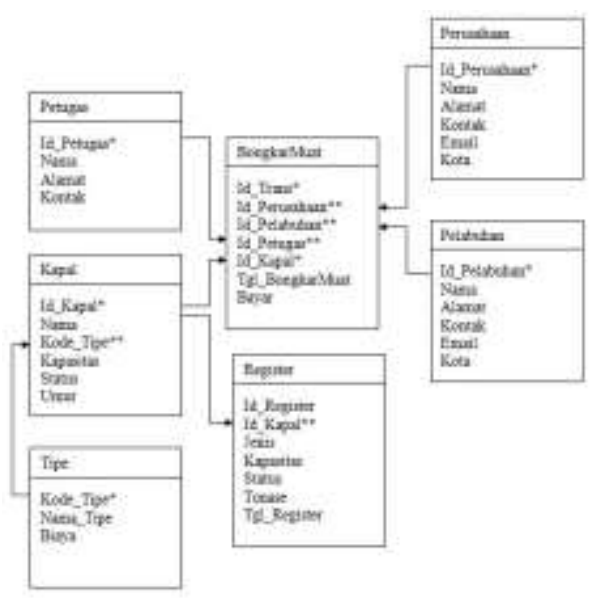

\section{HASIL DAN PEMBAHASAN}

1. Tampilan Antarmuka Utama Sistem Admin. Tampilan dibawah ini adalah tampilan halaman utama dari admin saat melakukan login. Dan input data

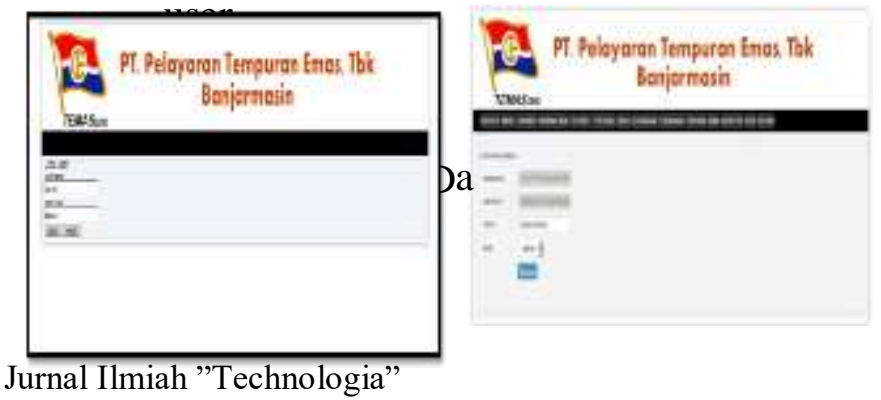

\section{Tampilan Data Register Kapal}

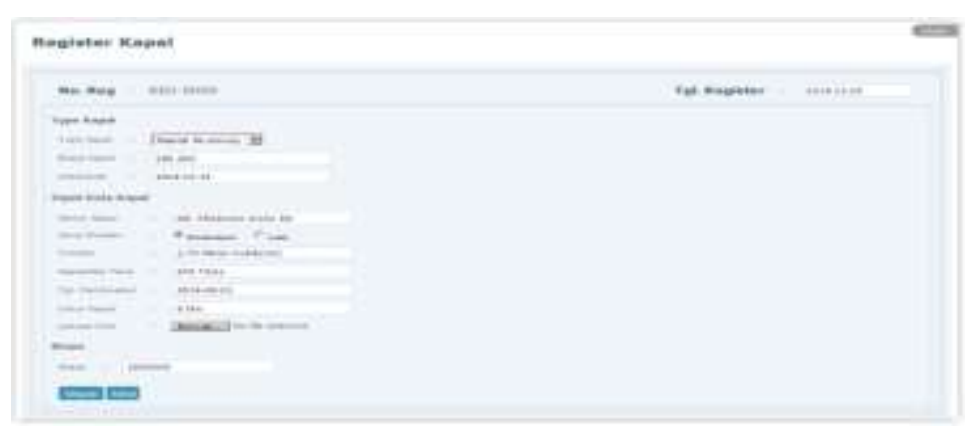

Form diatas data register sebelum memasuki pelabuhan atau dermaga kapal harus dirigester terlebih dahulu untuk melihat kelengkapan surat- surat kapal

\section{Tampilan Data Kapal}

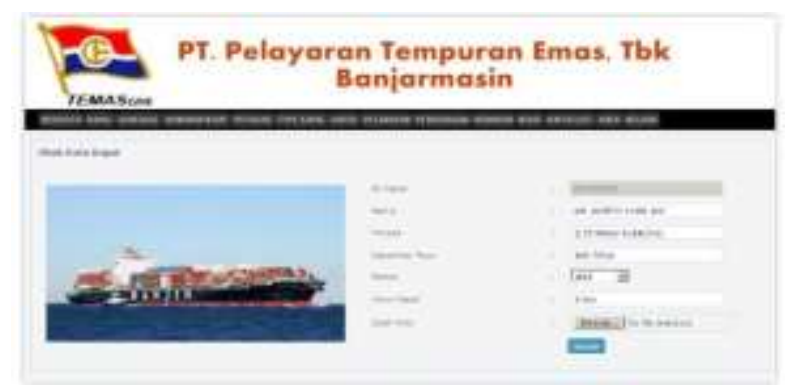

Form diatas tampilan jenis kapal atau nama kapal yang sedang merapat di pelabuhan

4. Tampilan Transaksi Bongkar dan Muat Kapal

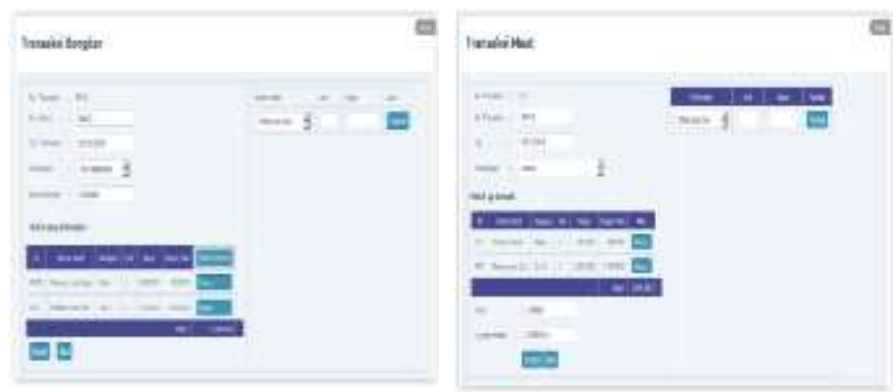

Form diatas adalah data transaksi yang mengelola barang menurunkan barang dan menaikan barang akan ditujukan di pelabuhan berikutya 
[3] Hafidz, M. (2014). Perancangan Sistem Informasi Keuangan Pada Info

\section{KESIMPULAN}

Setelah melalui beberapa tahapan dan pembahasan penelitian ini untuk menghasilkan Aplikasi Pelayanan Angkutan Kapal di PT pelayaran Tempuran Emas, TBK Banjarmasin Berbasis web, dengan melihat dari semua permasalahan, analisis, perancangan dan pembuatan sistem maka dapat ditarik kesimpulan diantaranya :

A. Aplikasi ini dapat digunakan pada komputer apa saja yang online atupun terhubung dengan jaringan lokal kantor.

B. Transaksi bongkar muat ini bermanfaat bagi perusahaan dalam hal pendataan dan pelaporan. Sehingga kinerja bagian kepegawaian menjadi lebih efektif dan efisien.

C.Sistem yang dikembangkan ini dapat diakses dengan satu hak akses yaitu administrator. Administrator secara penuh dapat mengubah data.

D. Melakukan pengoperasian sistem secara mudah dan praktis, meminimalis kesalahan kesalahan dalam transaksi bongkar muat serta membantu penyampaian informasi dengan menggunakan laporan yang sudah otomatis ada pada sistem.

\section{DAFTAR PUSTAKA}

[1] Edu Pampudi, S. (2015). Pengertian Sistem Informasi Manajemen Menurut Para Ahli.

[2] Fatta, A., \& Hanif. (2007). Analisis dan Perancangan Sistem Informasi untuk keunggulan bersaing perusahaan dan Organisasi Modern. Andi Offset.
Komputer Banjarmasin Menggunakan PHP. Universitas Pemulang. Banten.

[4] Jogiyanto, H. (2002). Analisis dan Desain Sistem Informasi Yogyakarta. Andi Offset.

[5] Kadir, A. (2002). Pengenalan Sistem Informasi Yogyakarta. Andi Offset.

[6] Kosasih, E. (2012). Definisi dan Pengertian Informasi Menurut Para Ahli.

[7] Kristanto, A. (2004). Rekayasa Perangkat Lunak. Gava Media.

[8] Kumiadi, D. (2013). Penjelasan Context Diagram dan Data Flow Diagram. 